\title{
USING VIRTUAL LABS TO ENHANCE STUDENTS' THINKING ABILITIES, SKILLS, AND SCIENTIFIC ATTITUDES
}

\author{
M. Firman Ramadhan ${ }^{1}$, Irwanto ${ }^{2}$ \\ ${ }^{1}$ Muhammadiyah University of Mataram, ${ }^{2}$ Yogyakarta State University \\ ${ }^{1}$ Firman1985VInstrumentation@gmail.com, ${ }^{2}$ Irwan_uny@yahoo.com
}

\begin{abstract}
Educational problems are very complex problems, so it takes a solution to overcome those problems, especially in the 21 st century. Educators are expected to disseminate learning by utilizing the development of 21 st century technology, educators must also be able to develop technology-based learning media with reference to the school curriculum. The transformation of technology in the digital era provides a wide range of beneficial effects on the science learning process. One important impact of the development in digital era that can be utilized in science education is virtual laboratory. Virtual laboratory is a media that can provide direct experimental visualizations, interactive virtual environment, practical experimentation, to de experiments more efficiently, and be able to save on purchasing experimental tools. Learning by using a virtual laboratory can also be done anywhere and anytime without taking the class lessons. This study is aimed to determine the effect of virtual laboratory based learning model on students' thinking abilities, skills, and scientific attitudes. This research used qualitative descriptive research method. The data analysis techniques used refers to the data analysis model by Miles \& Huberman (1994), including components: reduce data, display data, draw conclusions, and verify. This paper reviews the 23 articles on students' thinking abilities, skills, and scientific attitudes toward virtual laboratory. This paper has been published in Indonesia and several journals have a scopus index reputation from 2010 to 2016. The results showed that the virtual laboratory is able to enhance students' problem solving, critical thinking, creativity, conceptual understanding, science process skills, lab skills, motivation, interest, perception, and learning outcomes. Therefore, educators need to use virtual laboratories to improve teaching quality and student learning outcomes.
\end{abstract}

Keywords: virtual lab, thinking abilities, skills, scientific attitudes

\section{Introduction}

Science is a subject related to laboratory activities. It is a knowledge of natural phenomena involving inquiry and discovery through the hands-on and experiments under the guidance of the teachers [1]. In the science learning, the laboratory activity is much more important as providing opportunities for the students to perform various kinds of hands-on [2]. The laboratory activities are expected to help the students acquiring the technical skills. Through the experimental activities, the students will have direct experience, conceptual understanding, and long-term memory. Furthermore, current experiments can be carried out using developments in the field of information technology [3].

The development of digital era technology provides various positive impacts in supporting the success of science learning process. Information technology can be used as an alternative to facilitate the needs of interactive laboratories in schools. One impact of the development of the digital age that can be utilized in the field of education is a virtual laboratory. The virtual laboratory offers exciting lab processing and simulation facilities, the ease of use of tools, and more accurate results [4]. The virtual lab is a learning medium that can provide direct experimental visualization, interactive virtual environment, practical experimentation, and do the experiments more efficiently. Through the virtual lab activity, the students have the opportunity to repeat the wrong experiment and deepen the experience independently [5-6].

In practice, virtual labs provide various benefits in achieving the expected learning outcomes. The use of virtual laboratories addresses some of the problems encountered in traditional laboratories and contributes positively in achieving learning goals [3]. The virtual labs provide opportunities for learning by doing at a cheaper, more secure, and widely used cost [7]. Although the virtual labs cannot replace traditional laboratories, the use of the virtual labs greatly facilitates the learning process of science. However, the development of computer 
hardware and software enables educators to incorporate virtual technology into future teaching strategies recently [8].

The virtual laboratory uses computerized models, simulations, and various other instructional technologies to replace traditional lab activities [5]. It provides many advantages. It is done in the cyberspace so experimentation does not harm yourself or others. The affordable simulation costs, once developed, the tool can be used repeatedly at no additional cost. The virtual lab allows students to work independently or collaboratively regardless of the school laboratories, chemicals, and equipment available [9]. Thus, this study aims at determining the effect of the application of virtual lab aided learning to students' thinking, skills, and scientific attitudes.

\section{Method}

This study uses qualitative research methods. The qualitative research is an activity of collecting, analyzing, interpreting data, and reporting of interpretation result [10-11]. Content analysis is one of the qualitative research methods used to analyze and interpret textual data content [12]. In the research method, there are various data collection procedures, including tests, questionnaires, interviews, observations, diaries, and journals [13]. The data analysis techniques used refers to the data analysis model by Miles \& Huberman [14], including collection, reduction, presentation of data, and conclusions. In this study, the researchers conducted a content analysis of 23 papers about the benefits of virtual labs in science learning. The papers have been published in Indonesia from 2011 to 2016. This study has been being conducted from February to April 2017.

\section{Results and Discussion}

Research on the influence of learning model (assisted by Virtual Laboratory) and interest in learning on the ability of creative thinking chemistry. This research shows that there is influence of learning model with Virtual Laboratory assisted on creative thinking ability, interest in learning, interaction between learning model and interest in learning on creative thinking ability in chemistry subject. The results showed that there were two groups with different mean values of creative thinking ability on chemistry subjects and two groups did not have an average difference [15]. The Virtual Laboratory is able to increase students' learning motivation on chemistry subjects, the students' learning motivation on acidic and bases titration titration is categorized high with an average score of $73.28 \%$ [16]. Virtual Laboratory can influence psychomotor students on Reaction Rate practicum in Class XI Science SMAN 7 Sarolangun. The results showed that there was a significant effect on student psychomotor on reaction rate material in class XI Science 1 (experimental class) SMAN 7 Sarolangun [17]. While [18] conducted the application of Virtual Laboratory-based PHET Simulation with direct instruction. Student activity using the Virtual Laboratory (PHET Simulation) on the reaction rate material is categorized high. There is a difference in mean scores before and after learning, but there is no difference in the progress of experimental class learning with the control class. $87.72 \%$ of students said the virtual laboratory as the latest learning, ease to understand the lessons of $94.76 \%$, help complete the task and make it easier to solve the problem of $56.14 \%$, Increase student motivation $89.47 \%$, and virtual lab suitable for use in other subject equal to $82.46 \%$. [19] Virtual laboratory on chemistry subjects as an alternative learning to improve student learning outcomes at chemical tadris program at IAIN Walisongo Semarang. The use of Virtual Laboratories can effectively improve student learning outcomes. [6] The use of laboratory applications in learning chemistry is very important, so as to increase the influence of student achievement 90 students from 3 different classes in class IX. Data collection was used before and after learning using virtual lab and analyzed using SPSS version 16. The development of virtual laboratory applications developed has the same effect with the lab as well as in the introduction aspects of laboratory equipment and the improvement of student learning outcomes. The same is also explained by [3] in his research entitled The Effect of the Virtual Laboratory on Students' Achievement and Attitude in Chemistry. Learning chemistry using a virtual laboratory can help students understand learning and improve student learning interest, since learning using virtual laboratories is rarely used in Turkey. Prepared 16 experiments using virtual laboratory applications to help Turkish public schools and the results have a positive influence on improving student achievement and attitudes compared to conventional learning. [20] reveals that learning is more interesting, more effective, can summarize learning time, can improve the quality of learning and teaching and learning process can be done anywhere and anytime by utilizing virtual labs and E-Reference in the learning process and research on Chemistry. Cost savings of research and research that cannot be 
done because of the limitations of tools in the real laboratory. The weakness of the Virtual Laboratory for troubleshooting can be synergized with E-References.

Research conducted by [21] that the use of virtual lab media on physics subjects can influence student problem solving. The guided Inquiry learning model based on the real laboratory and virtual laboratory is better than the direct learning model as an effort to improve students' physics learning outcomes. The guided inquiry learning model in the real laboratory and virtual laboratory has significant interaction with the direct learning model so as to increase the activity and the students' learning outcomes on the subject of physics [22]. While [23] developed a virtual laboratory on kinematics material with vector analysis on physics lessons in Class XI. The virtual laboratory on Kinematic materials and Vector Analysis in the XI class of SMA deserves to be used in physics, practical and effective learning used in Physics learning can be seen from the increasing student learning outcomes. The activities and perceptions of students in applying virtual laboratory as a media of learning on modern physics in high school are in $80 \%$ of each criterion with regard to demostration, concept, calculation, problem practice, categorizing, explaining, presenting and creating process in learning. Whereas learners' perceptions about virtual lab implementation are in the strongly agreed category shown by $91.03 \%$ [24]. So also with the Student Perceptions of the Virtual Laboratory Utilization in Physics Learning Straight Motion Topics (Survey of Students of Class X SMAN 87 South Jakarta) received a positive response. Student understanding and learning experience can be improved by using a virtual laboratory, this is reinforced by student statements that most expressly agree to use virtual labs and students better understand the concept of straight motion [25]. The development of learning media in the form of virtual laboratories conducted by [26] to overcome misconceptions on core physics materials at SMAN 1 Binamu revealed the result that the instructional media in the form of virtual laboratory as a presentation model and tutorial on radioactive activity and the penetration of radioactive rays obtained valid results and Reliable. The virtual lab view comes with navigation, hints, hyperlinks to make it easier for users; Learning tools in the form of RPP, reading books, LKS made in softcopy and hardcopy so easy on autorun via $\mathrm{CD}$; Learner activity above $85 \%$ and learners' perceptions about virual laboratory of $93.05 \%$ indicating strongly agree;
There is a better understanding of concepts than before using a virtual lab. [27] conducted a study entitled The use of virtual and simulated teaching and learning environments: Inviting gifted students into science, technology, engineering, and mathematics careers (STEM) through summer partnerships. Based on the research result, it is found that students have motivation in learning by using technology. [28] research on Effects of 3D virtual simulators in the introductory wind energy course: a tool for teaching engineering concepts, This research provides innovative solutions in effective learning and is able to improve the postsecondary education by developing virtual simulators that can be integrated with the school curriculum. Critical acquisition of educating and training a professional generation in industry, the development and implementation of virtual simulators in the accompanying curriculum will foster national reform in the United States, Thus meeting the needs of the wind energy industry movement and addressing the broader educational issues in a number of disciplines. [29] Research on virtual laboratory and learning management system in optimal control theory education, learning using virtual lab and Remote in technical education designed using Java programming language. Development of a virtual laboratory that uses Java Simulations and is integrated with Moodle in control theory education. While [30] the use of virtual laboratory can improve students' skill in biology education program in using microbiology tools for 45 students taking microbiology courses. [31] Researching on Virtual Laboratory Implementation to Support High School Learning, some subjects require activity in laboratories such as Biology, Mathematics, Chemistry and Physics. It takes a laboratory tool that can be used anytime and anywhere so as not to interfere with the lesson, virtual lab is a computer application that can be used to experiment with low cost.

Effectiveness of the development of Virtual Laboratory can improve the ability to increase critical thinking but has no significant difference to the scientific attitude of high school students on the concept of metagenesis of moss and nail plants. This is indicated by the difference in mean value of critical thinking ability of class $X$ students of MIA 4 (Control class) with class $\mathrm{X}$ MIA 3 (experiment class) whereas students' scientific attitude there is no difference of average value in Control class and Experiment class [32] . Meanwhile, according to [33] who did research on A Virtual Lab in Research 
Methods. Virtual labs are superior to the real laboratory for the overall value earned. Because students prefer the convenience and ease in doing research. When compared to traditional learning, more time is needed in completing tasks and communicating with students. The results provide an overall assessment of the aspects of leadership, exercise questions, and values. There is a significant difference in the leadership aspect shown by $F(5.185)=5.8, p<0.0001$. Possible aspects of leadership have an effect on the exercise value rating and its parts. The leadership aspect correlates with exercise rank, $r(191)=$ $0.37, \mathrm{p}<0.0001$, and the assessment aspect, $\mathrm{r}$ $(191)=0.46, p<0.0001$. Virtual labs can be easily applied to modifications that can be adapted to the curriculum. It is also suggested by [34] who studied the Out of the classroom and into the laboratory: Teaching digital curation virtually and experientially. Virtual labs must be able to complete and refine the latest curriculum in digital subjects. The digital learning is offered at the LIS School at Simmons College, Boston which describes the virtual and experimental approach as an innovative learning. There is a relationship between the digital curriculum laboratory, the successful delivery of a digital curriculum and has broader implications. So it is with [35] who is researching about A Systematic, Inquiry-Based 7-Step Virtual Worlds Teacher Training. This study determines teachers' perceptions of the effectiveness of virtual teacher training using systematic 7 steps, determining teacher attitude change due to involvement in this workshop activity. Changes in attitudes of teachers were statistically significant with large effect sizes, the effectiveness of teacher training resulted in 14 practical guidelines that could inform teacher training models using virtual laboratories by revising 4 steps so that they could be used generally or specifically with little adaptation depending on teacher and student population.

Based on the 23 articles reviewed, virtual labs have a positive effect on improving problem solving skills, critical thinking, creative, conceptual understanding, science process skills, lab tool skills, motivation, interests, perceptions, and learning outcomes. Educators are expected to be able to develop or apply learning using virtual labs tailored to the curriculum in schools. The use of virtual labs can reduce the purchase of laboratory tools and learning by using a virtual laboratory can be done anywhere and anytime without interrupting the classroom learning time.

\section{Conclusion}

The results showed that the virtual laboratory is able to enhance students' problem solving, critical thinking, creativity, conceptual understanding, science process skills, lab skills, motivation, interest, perception, and learning outcomes. Therefore, educators need to use virtual laboratories to improve teaching quality and student learning outcomes.

\section{ACKNOWLEDGMENT}

The authors would like to express profound thanks and appreciation to Directorate of Higher Education, Ministry of Research, Technology and Higher Education Republic of Indonesia through "BUDI-DN" for the financial support.

\section{REFERENCES}

[1] J. Copriady, "Teachers competency in the teaching and learning of chemistry practical," Mediterranean Journal of Social Sciences, vol 5, pp.312-318, 2014.

[2] G. Demircioğlu and M. Yadigaroğlu, "The effect of laboratory method on high school students' understanding of the reaction rate," Western Anatolia Journal of Educational Sciences, Special Issue: Selected papers presented at WCNTSE, pp.509-516, 2011.

[3] C. Tüysüz, "The effect of the virtual laboratory on students' achievement and attitude in chemistry," International Online Journal of Educational Sciences, vol 2, pp.37-53, 2010.

[4] R. Md Zahidur, "Teaching electrical circuits using a virtual lab," In Transit: The LaGuardia Journal on Teaching and Learning, vol 6, pp.85-92, 2014.

[5] R.K. Scheckler, "Virtual labs: a substitute for traditional labs?" The International Journal of Developmental Biology, vol 47, pp.231-236, 2003.

[6] Z. Tatli and A. Ayas, "Effect of a virtual chemistry laboratory on students' achievement," Educational Technology \& Society, vol 16, pp.159-170, 2013.

[7] L. Rajendran, R. Veilumuthu, and J. Divya, "A study on the effectiveness of virtual lab in E-learning," International Journal on Computer Science and Engineering, vol. 2, pp.2173-2175, 2010.

[8] H. El-sadi, "Project based learning - virtual lab: heat transfer," International Journal of 
Engineering and Technology, vol 5, pp.290$296,2015$.

[9] N.R Herga, B. Čagran, and D. Dinevski, "Virtual laboratory in the role of dynamic visualisation for better understanding of chemistry in primary school," Eurasia Journal of Mathematics, Science \& Technology Education, vol 12, pp.593-608, 2016.

[10] J. Iacono, A. Brown, and C. Holtham, "Research methods - a case example of participant observation," Electronic Journal of Business Research Methods, vol 7, pp.3946, 2009.

[11] S. Elo, M. Kääriäinen, O. Kanste, T. Pölkki, K. Utriainen, and H. Kyngäs, "Qualitative content analysis: a focus on trustworthiness," SAGE Open, pp.1-10, 2014.

[12]H-.F. Hsieh and S.E. Shannon, "Three approaches to qualitative content analysis," Qualitative Health Research, vol 15, pp.1277-1288, 2005.

[13]M. Zohrabi, "Mixed method research: instruments, validity, reliability and reporting findings," Theory and Practice in Language Studies, vol. 3, pp. 254-262, 2013.

[14]M.B. Miles and A.M. Huberman, An expanded sourcebook qualitative data analisys, Thousand Oaks: SAGE Publication, 1994.

[15] Pujiati, A.. Pengaruh Model Pembelajaran (Berbantuan Laboratorium Virtual) dan Minat Belajar Tehadap Kemampuan Berpikir Kreatif Kimia. Jurnal Formatif 2(3): 182-189. 2012.

[16]Ikhsan, M. and Afdal. Kajian Motivasi Belajar Siswa Dalam Pembelajaran Kimia Menggunakan Virtual Lab. Jurnal Pendas Mahakam.Vol.1 (1). 65-68. 2016.

[17]Haryanto. Pengaruh Penggunaan Laboratorium Virtual Terhadap Psikomotor Siswa Pada Praktikum Laju Reaksi Kelas XI IPA SMAN 7 Sarolangun. Prosiding Semirata FMIPA Universitas Lampung. 2013.

[18] Sumargo, E. and Yuanita, L.. Penerapan Media Laboratorium Virtual (PhET) Pada Materi Laju Reaksi Dengan Model Pengajaran Langsung. Unesa Journal of Chemical Education, Vol.3, No. 1, pp. 119133. 2014.
[19] Mulyatun. Laboratorium Kimia Virtual: Alternatif Pembelajran Kimia untuk meningkatkan Hasil Belajar Mahasiswa Tadris Kimia IAIN Walisongo Semarang. Jurnal Inovasi Pendidikan Kimia, Vol.6, No.2. 2012.

[20] Nirwana, R. R. Pemanfaatan Laboratorium Virtual dan E-Reference dalam Proses Pembelajaran dan Penelitian Ilmu Kimia. Jurnal PHENOMENON, Volume 1 Nomor 1. 2011.

[21] Darti, E. Y., Fuadunazmi, M., and Budi P, D. S. Pengaruh Penggunaan Media Laboratorium Virtual Fisika Terhadap Kemampuan Pemecahan Masalah Siswa. Jurnal Ilmiah Pendidikan Fisika "Lensa", Vol. 3 No.2. 2015.

[22] Simbolon, D. H. and Sahyar . Pengaruh Model Pembelajaran Inkuiri Terbimbing Berbasis Eksperimen Riil dan Laboratorium Virtual terhadap Hasil Belajar Fisika Siswa. Jurnal Pendidikan dan Kebudayaan, Vol. 21, Nomor 3. 2015.

[23]Putri, A., Syakbaniah, and Yulkifli. Pengembangan Virtual Laboratory pada Materi Kinematika dengan Analisis Vektor dalam Pembelajaran Fisika di Kelas XI SMA. Pillar of Physics Education, Vol. 1., 23-29. 2013.

[24] Azis, A. dan Yusuf, I. Aktivitas dan Persepsi Peserta Didik dalam Implementasi Laboratorium Virtual Pada Materi Fisika Modern Di SMA. Berkala Fisika Indonesia, Volume 5 Nomor 2. 2013.

[25] Safitri, H. and Herawati. Persepsi Siswa Terhadap Pemanfaatan Laboratorium Virtual Dalam Pembelajaran Fisika Topik Gerak Lurus (Survey Terhadap Siswa Kelas X SMAN 87 Jakarta Selatan). Jurnal Pendidikan, Volume 12, Nomor 2, September 2011, 97-101. 2011.

[26] Swandi, A., Hidayah.LJ, S. N., and Irsan. Pengembangan Media Pembelajaran Laboratorium Virtual untuk Mengatasi Miskonsepsi Pada Materi Fisika Inti di SMAN 1 Binamu, Jeneponto. Jurnal Fisika Indonesia No: 52, Vol XVIII. 2014.

[27] Dieker, L., Grillo, K. and Ramlakhan, N. The use of virtual and simulated teaching and learning environments: Inviting gifted students into science, technology, engineering, and mathematics careers (STEM) through summer partnerships. 
Gifted Education International 28(1) 96106. 2012.

[28] Do, Phuong T., Moreland, John R., Delgado, C., Wilson, K., Wang, X., Zhou, C., and Ice, P. Effects of $3 \mathrm{D}$ virtual simulators in the introductory wind energy course: a tool for teaching engineering concepts. Innovative Teaching. Volume 2 Article 7 ISSN 2165 2236. 2013.

[29] Popovic', N. and Naumovic', M. B. Virtual Laboratory and Learning Management System in Optimal Control Theory Education. International Journal of Electrical Engineering Education. 2016.

[30]Herrani C. R.. Penggunaan Virtual Lab untuk Meningkatkan Keterampilan mahasiswa pendidikan biologi dalam menggunakan alat-alat mikrobiologi. Widya Dharma Jurnal Kependidikan, Vol 27, No.2. 2015.

[31] Hidayat, A. and Utomo, V. G. Virtual Laboratory Implementation to Support High School Learning. International Journal of Computer Applications (0975 - 8887) Volume 120-No.16. 2015.

[32] Rasyida, N., Tapilouw, F. S. and Priyandoko, D. Efektivitas Pengembangan Praktikum Virtual Untuk Meningkatkan Kemampuan Berpikir Kritis Dan Sikap Ilmiah Siswa Sma Pada Konsep Metagenesis Tumbuhan Lumut Dan Paku. Prosiding Seminar Nasional Pendidikan Biologi. 2015.

[33] Sommer, B. A. dan Sommer, R. A Virtual Lab in Research Methods. Teaching of Psychology. 2015.

[34] Harvey, R. and Bastian, J. A. Out of the classroom and into the laboratory: Teaching digital curation virtually and experientially. International Federation of Library Associations and Institutions 38(1) 25-34. 2012.

[35] Nussli, N. and Oh, K. A Systematic, InquiryBased 7-Step Virtual Worlds Teacher Training. E-Learning and Digital Media 0(0) 1-28. 2016. 